\title{
MANAGE CO-USE WITH QUALITY FUNCTION DEPLOYMENT (QFD) FOR QUALITY AND SUSTAINABILITY
}

\author{
UPRAVLJATI ZAJEDNIČKOM PRIMJENOM RAZVOJA \\ KVALITETE FUNKCIJE (QFD) ZA KVALITETU I ODRŽIVOST \\ Dr. Catherine Y. P. Chan \\ Hong Kong Quality Function Deployment Association \\ Hong Kong, China/Kina \\ E-mail: catherine@qfdhk.org
}

UDK/UDC: 005.642.1:502.131.1

JEL klasifikacija/JEL classification: L15; Q56

DOI: $10.30657 /$ hdmk.2020.07

Pregledni članak/Review

Jezik/Language: Engleski/English

\begin{abstract}
Despite co-use is effective for sustaining our one and only planet and beneficial to both users and providers in the market, problems with delivery and use of co-use services are growing. Complaints from users and conflicts between users in using the service have been getting more and more. Reasons leading to the problems, of course, are numerous. However, from the perspective of quality management, a major reason is the needs of the involved users have not yet been fully met. To help service providers alleviate the problems, the aim of the paper is to discuss the important points for applying quality function deployment (QFD) to understand the needs of the users that involved in a co-use service and to offer some suggestions for managing the delivery of co-use services. The discussion on QFD application and the suggestions that offered would help service providers contribute to raising their delivery quality and support them on developing co-use as a way for sustaining our society and the globe.
\end{abstract}

Key words: Quality function deployment, co-use, sustainability.

\section{INTRODUCTION}

Under the thrust of sustainability, co-use has quickly developed into a widespread format of service provision as well as major mode of consumption. Despite co-use is effective for sustaining our one and only planet and beneficial to both users and providers in the market, problems with delivery and use of co-use services are growing. Complaints from users and conflicts between users in using the service have been getting more and more. Reasons leading to the problems, of course, are numerous. Customer dissatisfaction has markedly increased. If service providers could not ease the problems, the harmony of the society would be affected and more wastes might also be created. Reasons leading to the problems, of course, are numerous. However, from the perspective of quality management, a major reason is the needs of the involved users have not yet been fully met. 
Although service providers will rectify the problems as soon as they have found or have been informed, the actions that taken afterwards could only prevent customer dissatisfaction from intensifying. Such remedial approach is similar to that of the manufacture industry in Japan in the 1960s for improving their offered products. After recovering from the World War II, the major manufacturers started launching their products to the local consumer market. As the manufacturers had not yet fully understood what the consumers exactly want and actually require, all they could do was to adjust or to improve their products when they had received feedback, and, at the same time, present a great variety of models for consumers to select. ${ }^{1}$ The point is responding to meeting the customers' needs in such reactive ways could hardly win their satisfaction; and, it would increase product development and production costs as well. To help manufacturers create design quality for their products, Yoji Akao and Shigeru Mizuno formulated quality function deployment (QFD) - a practical method which manufacturers could use to understand the customers' needs and make plans for meeting the needs.

Firmly adhered to Juran's notion of "fitness for use", QFD has been emphasizing the importance of meeting the needs with use in creating quality since it was introduced. Over the years, the way of understanding and meeting the customers' needs which QFD suggests has assisted hundreds of thousands of corporations and organizations in different ways and of multiple aspects for improving the existing and developing new products and services. In recent years, QFD has been taken up to the society level for addressing the needs of stakeholders and managing the needs from with use to not-use. ${ }^{2,3}$ To deliver quality co-use services in the growingly diversified and complex urban cities, properly meeting the needs of every user group; and, at the same time, skilfully managing every situation in which co-use is involved is of paramount importance. To help service providers alleviate the problems, the aim of the paper is to discuss the important points for applying quality function deployment (QFD) to understand the needs of the users that involved in a co-use service and to offer some suggestions for managing the delivery of co-use services. The discussion on QFD application and the suggestions that offered would help service providers contribute to raising their delivery quality and support them on developing co-use as a way for sustaining our society and the globe.

\section{QUALITY FUNCTION DEPLOYMENT (QFD)}

QFD is a comprehensive quality assurance system founded in Japan in the mid-1960s. Quality assurance, represented by Ishikawa as a type of promise or contact with consumers regarding quality ${ }^{4}$, is the central theme of companywide quality control (CWQC). In view of the need for a quality assurance system by the industry, the research on quality assurance of product design of Yoji Akao together with the profound work on CWQC of Shigeru Mizuno led to the formulation of QFD. By making use of the concepts of "network of quality" and control points, QFD has successfully provided corporations with a holistic system for implementing quality assurance from design all the way down to production. ${ }^{5}$ More than a system, the operation process of QFD, which performed in accordance to the basic principles and practices of CWQC, would enhance the understanding of the team members with the

\footnotetext{
${ }^{1}$ Masao Kogure, and Yoji Akao, "Quality function deployment and CWQC in Japan: a strategy for assuring that quality is built into new products", Quality Progress, October, 1983, pp. 25-29.

${ }^{2}$ Catherine Y. P. Chan, "QFD for achieving business excellence and attaining sustainability", Proceedings of the ISQM, Tainan, Taiwan, $19^{\text {th }}$ November, 2016.

${ }^{3}$ Catherine Y. P., Chan, and Glenn H. Mazur, „A framework of "use” for QFD”, Transactions from the $25^{\text {th }}$ Symposium on Quality Function Deployment, Boise, Idaho, USA, $6^{\text {th }}-7^{\text {th }}$ September, 2019.

${ }^{4}$ Kaoru Ishikawa, Introduction to Quality Control, 3A Corporation, Tokyo, 1990.

${ }^{5}$ Yoji Akao, "History of quality function deployment in Japan”, In: Zeller, H. J. (Ed.) The Best on Quality: Targets, Improvement, Systems, Vol. 3, pp. 183-196, Muchen: C. Hanser, 1990.
} 
problems and the needs they are working on, which would greately contribute to inpsiring the team members on coming up with new ideas and teaming up their efforts for formulating effective solutions. ${ }^{6}$

There are two kinds of deployment in QFD: (1) interpretation, and, (2) conversion. Conversion deployment is extremely helpful in translating items of one aspect, for instance, the given requirements, into items of another aspect, such as the features, the parts and the processes, which would collectively contribute to meeting the given requirements. However, it could not offer any help on finding out the items at the origin, that is, the needs of the customers with the product. The formulation of interpretation deployment has overcome this limitation. This added kind of deployment is a process starting from collecting the voice of the customer (VOC) from various sources, extracting need items from the collected VOC, organizing the need items into needs to, finally, identifying the important needs - the control points for assuring the design quality. Upon completed interpretation deployment, the team could continue with using conversion deployment to derive the key items and components constituting the make and the production quality. By supplementing conversion deployment with interpretation deployment, the resultant system enables implementing quality assurance at every stage of manufacture. ${ }^{7,8,9}$

With the impressive results obtained by Toyota in the early 1970s, QFD was quickly spread among its suppliers and further in the automotive industry. ${ }^{10}$ Together with the success obtained from the QFD applications made by some prominent companies, QFD quickly disseminated in many other manufacture industries and entered the high growth period in its homeland in the 1970s and 1980s. Towards the end of the 1970s, QFD started getting across to other parts of the world ${ }^{11}$, and, widespread in the service industry.

\section{CO-USE}

In a co-use, there are two or more users. The users could be of the same user group or come from different user groups. Each user group has its unique characteristics and certain needs of its own. Some of the characteristics and the needs, of course, are in common with some or even all of the user groups.

Figure 1. Sequential form and simultaneous form of co-use

\footnotetext{
${ }^{6}$ Catherrine Y. P. Chan, and Palmira López-Fresno, "QFD: fundamentality for innovation”, Proceedings of the $14^{\text {th }}$ International Conference on Intellectual Capital, Knowledge Management \& Organisational Learning, Hong Kong, $7^{\text {th }}-8^{\text {th }}$ December, 2017

7 Yoji Akao, “An Introduction of quality function deployment”, In: Akao, Y. (Ed.) Quality Function Deployment: Integrating Customer Requirements into Product Design, pp. 1-11, Cambridge, Mass.: Productivity Press, 1990.

${ }^{8}$ Yoji Akao, "Development history of quality function deployment", In Mizuno, S., and Akao, Y. (Eds.), QFD: The Customer-driven Approach to Quality Planning and Deployment, pp. 339-351, Tokyo, Japan: Asian Productivity Organization, 1994.

${ }^{9}$ Yoji Akao, “QFD: past, present and future”, Proceedings of the $3^{\text {rd }}$ Annual International QFD Symposium”, Vol. 1, Linköping, Sweden, 1997.

${ }^{10}$ Lawrence R. Guinta and Nancy C. Praizler, The QFD Book: The Team Approach to Solving Problems and Satisfying Customers through Quality Function Deployment, Amercian Management Association, 1993.

${ }^{11}$ Catherine Y. P. Chan, Palmira López-Fresno and Yoji Akao, "QFD from Japan to Global: history of QFD", Transactions from the $19^{\text {th }}$ International Symposium / the $25^{\text {th }}$ North America Symposium on Quality Function Deployment, pp. 1-28, Santa Fe, New Mexico, USA, 6 ${ }^{\text {th }}-7^{\text {th }}$ September, 2013.
} 
Sequential Form of Co-use
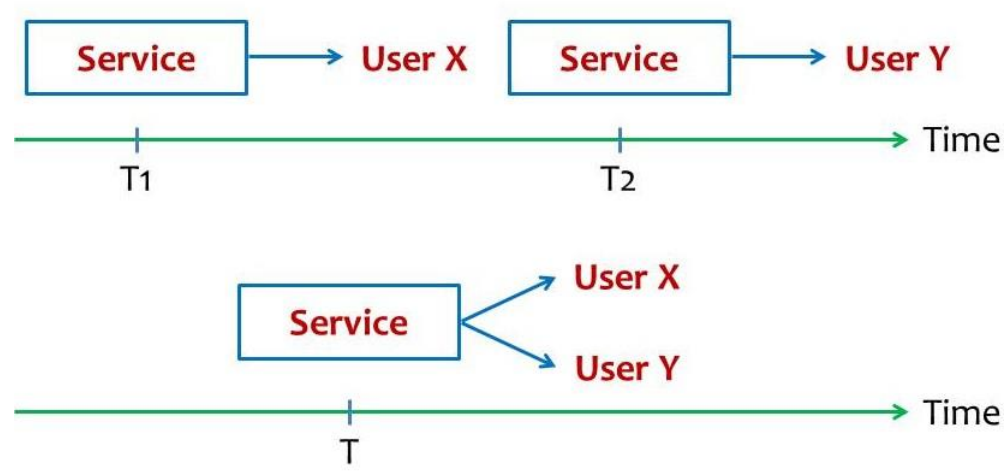

Simultaneous Form of Co-use

Source: Catherine Y. P. Chan and Glenn H. Mazur, "A framework of "use" for QFD", Transactions from The $25^{\text {th }}$ Symposium on Quality Function Deployment, Boise, Idaho, USA, $6^{\text {th }}-7^{\text {th }}$ September, 2019.

For services, co-use could be classified in two major forms in term of time: (1) sequential, and, (2) simultaneous. For sequential co-use, users or user groups do not use the service at the same time. However, for simultaneous co-use, users or user groups use the service in a co-existing manner. Figure 1 is a diagrammatic representation of these two forms of couse.

\section{IMPORTANT POINTS FOR APPLYING QFD TO CO-USE}

To understand the needs with using a product or a service, it is very necessary to clearly identify who use the product or the service and whose needs the product or the service is going to satisfy. For example, in the QFD project on developing a folding bicycle, the team defined the target customers and specified the characteristics for this customer group as male whitecollar workers in the age of 20-40 who use bicycles for commuting and for leisure. ${ }^{12}$ This step is vital for understanding the users' needs of both sequential co-use and simultaneous co-use. First, defining the user group, or in marketing term, the target customers, draws the domain for need exploration so that the chance of resulting with contradictory needs would be greatly reduced. Second, sensible solutions would more likely be devised if the needs are reviewed and considered group by group.

\subsection{Conduct Need Exploration User Group by User Group}

The first activity of need exploration is to collect VOC, a raw form of data that would inform the team about the needs of the customers. QFD suggests employ multiple methods to collect VOC for two main reasons. First, different approaches would help acquire a better understanding with the problem. For example, in a QFD project on designing an electric wheelchair, the team besides arranged focus groups to listen to the current users but also conducted an activity analysis to understand the situations in which the electric wheelchair was used. ${ }^{13}$ Second, the collection process provides the team with an opportunity to understand and

\footnotetext{
${ }^{12}$ Yoji Akao, "A case study on the development of a folding bicycle", Transactions from International Symposium on QFD 2010-Portland / the 22 $2^{\text {nd }}$ Symposium on Quality Function Deployment, pp. 1-14, Portland, Oregon, USA, $24^{\text {th }}-25^{\text {th }}$ September, 2010.

${ }^{13}$ Ingela Friman, "User requirements for electric wheelchairs", In Bühler, C., and Knops, H. (Eds.), Assistive Technology on the Threshold of the New Millennium, pp. 204-208, Washington DC: IOS; Tokyo: Ohmsha, 1999.
} 
to experience the needs with use and the problems the users faced in person. For examples, the engineers of the design team of a dinosaur robot as a park attraction visited a petting zoo in Toronto to observe how children interact with live animals in order to simulate a triceratops encounter; ${ }^{14}$ and, Nokia conducted a gemba visit in the Tokyo metropolitan area to capture the basic and the latent needs of cellular phone users. ${ }^{15}$

Although using multiple methods is effective for collecting a wider set of VOC, the collected set of VOC would not be informative if the collection methods have not yet been well planned. To facilitate discussion and drawing up the plan, the team could make use of the conversion deployment of QFD. By deploying the characteristics of the user group into features of and requirements for capturing VOC, the deployed features and requirements could provide the ground for the team to formulate, evaluate and/or select the collection methods.

For simultaneous form of co-use, to avoid confusion in the deployment process and contradiction of the explored needs, the team has to group the users or the target customers in sensible ways and use appropriate methods to collect VOC. For example, in a development project of a phone service company, because of the huge number of clients, the team employed a great variety of methods, including diary method, group interview, critical incident and problem detection, to collect the "Whats" for QFD. However, some problems with analyzing the data and deriving solutions were countered. ${ }^{16}$ Among the reasons for causing the problems, unclear separation should be a significant one.

The author would like to use a case study which she and her team conducted for understanding the passengers' ride needs of an urban rail ${ }^{17}$ to suggest one of the ways for grouping the users or the target customers for the case of simultaneous co-use. The overall aim of the study was to suggest the rail transit service provider on how to improve the ride quality in regard to the growing chaos inside the train cars. Although safe and comfortable ride is a common need of all passengers when they stay on the train, the meaning of "safe" and the meaning of "comfortable" could differ from one passenger group to another passenger group in regard to respective characteristics and situations. Therefore, it is necessary to put the passengers into appropriate groups in accordance to the subject matter that under studied. For this case, the team divided the passengers of into three groups: (1) everyday ordinary passengers, (2) visitors, and, (3) those required special care; and, specified the characteristics of each group. Figure 2 displays the three passenger groups and their relationships.

Figure 2. Three major passenger groups of urban rail

\footnotetext{
${ }^{14}$ Andrew Bolt and Glenn H. Mazur, "Jurassic QFD: integrating service and product quality function deployment", Transactions from the $11^{\text {th }}$ Symposium on Quality Function Deployment, pp. 463-478, Novi, Michigan, USA, $12^{\text {th }}$ $18^{\text {th }}$ June, 1999.

${ }^{15}$ Eric Ronney, Peter Olfe and Glenn H. Mazur, "Gemba research in the Japanese cellular phone market", Transactions from International Symposium on QFD 2000-Novi / the $12^{\text {th }}$ Symposium on Quality Function Deployment, pp. 358-374, Novi, Michigan, USA, $5^{\mathrm{h}}-6^{\mathrm{h}}$ June, 2000.

${ }^{16}$ Fredrik Ekdahl, Anders Gustafsson and Per Norling, "QFD for service development: a case study from Telia Mobitel", Proceedings of the $3^{\text {rd }}$ Annual International QFD Symposium", Vol. 2, Linköping, Sweden, 1997.

${ }^{17}$ Catherine Y. P., Chan, Kwai-Sang Chin, Candace Chan and Kwok L. Tsui,"'An analysis of passengers' ride needs of urban rail transit services: application of quality function deployment", International Journal of Quality Innovation, Vol. 5, No. 8, 2019.
} 


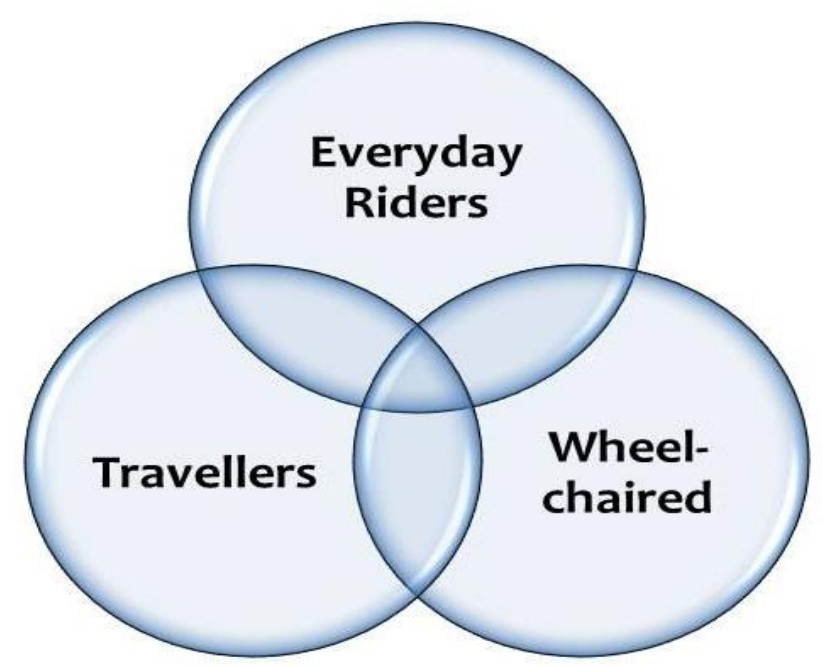

Source: Catherine Y. P., Chan, Kwai-Sang Chin, Candace Chan and Kwok L. Tsui, “An analysis of passengers' ride needs of urban rail transit services: application of quality function deployment", International Journal of Quality Innovation, Vol. 5, No. 8, 2019.

Separate projects were set up to study the ride needs of each of the three passenger groups (Figure 3). For each passenger group, the team used the methods of gemba visiting and dialoguing with customers to collect VOC. The collected VOC was interpreted into need items, the need items were clustered into needs. Last but not least, important needs were identified from the list of needs.

Figure 3. Conduct need exploration one passenger group by one passenger group

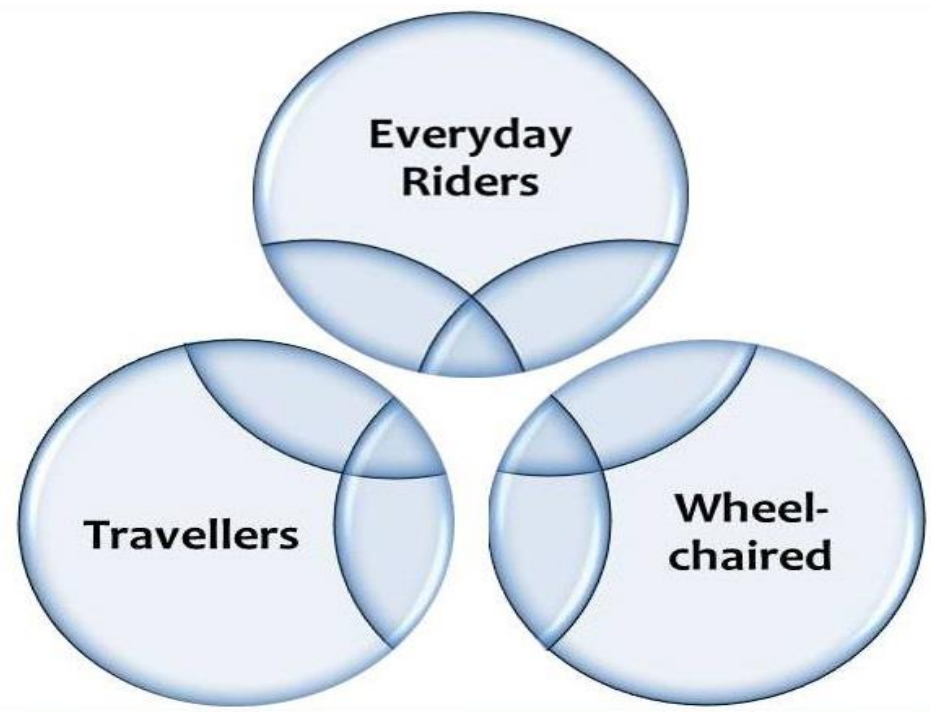

Source: Catherine Y. P., Chan, Kwai-Sang Chin, Candace Chan and Kwok L. Tsui, “An analysis of passengers' ride needs of urban rail transit services: application of quality function deployment", International Journal of Quality Innovation, Vol. 5, No. 8, 2019.

One may argue why not putting all groups into one study so that the team could find out the teams of the three passenger groups all at one time. However, it is better to carry out 
individual studies as there is a chance the important needs that identified are only applicable to one or two passenger groups rather than to all passenger groups.

\subsection{Investigate Inter-relationships of the Important Needs Among the User Groups}

It is necessary to reconcile the overall needs upon completed the individual projects. Investigating the inter-relationships of the important needs among the user groups is necessary to draw up a practical plan for making sensible actions. The output of the investigation could be one whole set of needs but also could be several sets of needs. With the needs, the team only continue with applying the conversion deplopyment of QFD to help formulate solutions. Upon identifying the imporant quality elements, engineers and designers will definitely know much better how to satisdfy the needs.

Service providers, especial those serving the public at large, need to cater the interests and the concerns of multiple customers or stakeholders. Education is a typical example. For some cases, the team identified the important needs by assigning different weights to the responses of the groups. In improving the educational quality of an engineering discipline, students, employers and faculty members were invited to prioritize the competencies required of the graduates. ${ }^{18}$ Likewise, the three stakeholder groups, these being students, faculty members and employers, were asked to prioritize seven given educational processes to identify the areas of improvement for an engineering department. The ratings given by the three stakeholder groups were allocated with different weights so as to reconcile their respective degrees of importance in the final decision. ${ }^{19}$ In the design of an engineering curriculum, besides employers, faculty and students, students' parents were also invited to express their expectations and identify the important qualities which the graduates were expected to possess. ${ }^{20} \mathrm{~A}$ weighing method was once again used to reconcile the importance ratings of the stakeholder groups. Instead of balancing the stakeholders' needs by weights, the design of an introductory course in Engineering Graphics at Georgia Southern University used obtaining consensus as the method for resolving the difference in opinions between the employers, professional societies and accreditation boards on the quality requirements of the graduates. ${ }^{21}$ The problem with these cases was the needs of the involved parties were assumed to be of the same level and similar in nature, with the only area of difference between the stakeholders was the magnitude of the importance of the needs. However, the needs and views of various stakeholder groups may not always coincide, especially those of employers and students. Their interests and needs are in the domain of education but might be of different aspects.

\section{CO-USE REQUIRES THE NEEDS OF EACH USER GROUP PROPERLY MET}

\footnotetext{
${ }^{18}$ Gülser Köksal and A. Eğitman, "Planning and design of industrial engineering education quality", Computers Industrial Engineering, Vol. 35, No. 3-4, 1998, pp. 639-642.

${ }_{19}$ Mohammad S. Owlia and Elaine M. Aspinwall, "Application of quality function deployment for the improvement of quality in an engineering department", European Journal of Engineering Education, Vol. 23, No. 1, 1998, pp. 105-115,

20 Nirachara Boonyanuwat, Sakesun Suthummanon, Napisporn Memongkol and Supapan Chaiprapat, "Application of quality function deployment for designing and developing a curriculum for industrial engineering at Prince of Songkla University", Songklanakarin Journal of Science Technology, Vol. 30, No. 3, 2008. pp. 349353.

${ }^{21}$ Anoop Desai and Jean-Claude Thomassian, "Engineering course design based on quality function deployment (QFD) principles: incorporation of diverse constituencies and continuous improvement", Proceedings of the $38^{\text {th }}$ ASEE/IEEE Frontiers in Education Conference, Session T2G, 2008, pp. 17-21.
} 
For sequential form of co-use, users or user groups do not use the service at the same time. There is a pause between two consecutive uses, with the pause serves as a partition for separating the use of the service for two different users. This time gap is important as the service provider could use it to make sure the service is what required by the next user or user group. If this partition is not properly managed, then co-use could easily end in disaster. An example is some unsuccessful bike-sharing cases recently reported from various places. The reasons behind the failure, of course, are diversified. However, from the angle of co-use, not all users could receive what required, that is, a bike in good condition, from the service is a major reason (Figure 4). Bike-sharing is a good business idea for sustainability. Its success depends on a joint effort of service providers and users. Whilst users are developing the responsibility of taking care of their borrowed bikes, service providers have to find ways to ensure the quality of every bike for every user.

Figure 4. Not every user receives the required quality with bike-sharing

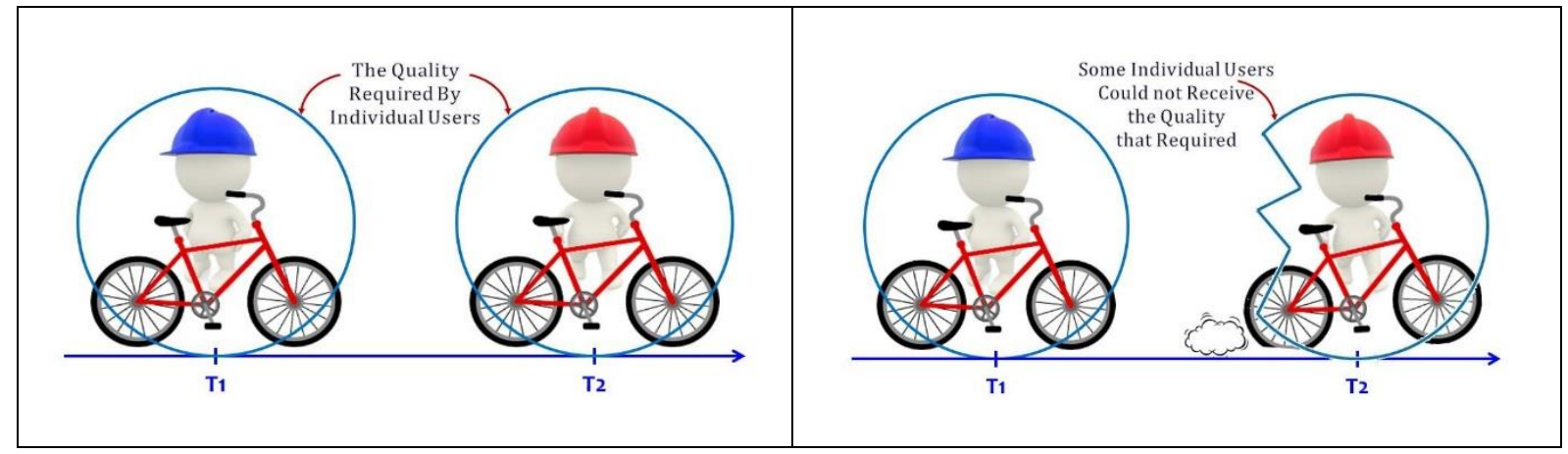

Source: Made by author.

For simultaneous form of co-use, again, poor management with the partition is a major reason for causing chaos. In many cases, the use of the service of a group or certain groups has crossed into that of others. Getting back to the train cars of urban rail, the suitcases and large packages that parked near the train doors have blocked the way of other passengers for getting in and off the train, in particular during the peak hours. In general, passengers have been trying their best to accommodate the "crossed use" of one another. However, if the "crossed use" has exceeded the tolerance of many passengers, then conflicts between passengers would easily occur (Figure 5).

Figure 5. Conflicts would occur if "crossed use" has exceeded passengers" tolerance 


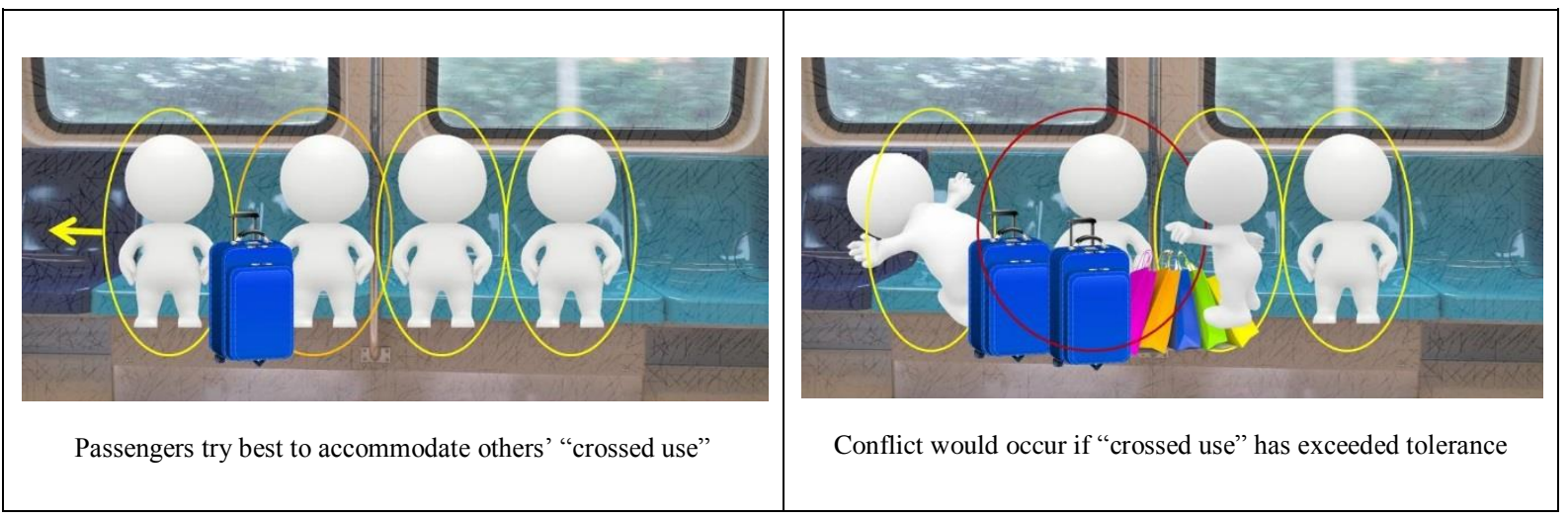

Source: Made by author.

Inserting partition is an effective way for avoiding conflicts. Depending on individual conditions, the kinds of partition to be inserted would vary from rail line to rail line. Separating large objects from passengers within a train car, allocating different train cars for different passenger groups and taking some measures for dividing the passenger groups at certain crowded commute times are some methods many rail lines use. Appropriate infrastructures, even as simple as the ways as a rail line is using, as shown in Figure 6, not only are effective for reducing conflicts between passengers inside a train car but also improving the overall ride quality.

Figure 6. Examples of appropriate infrastructures for acting as partitions

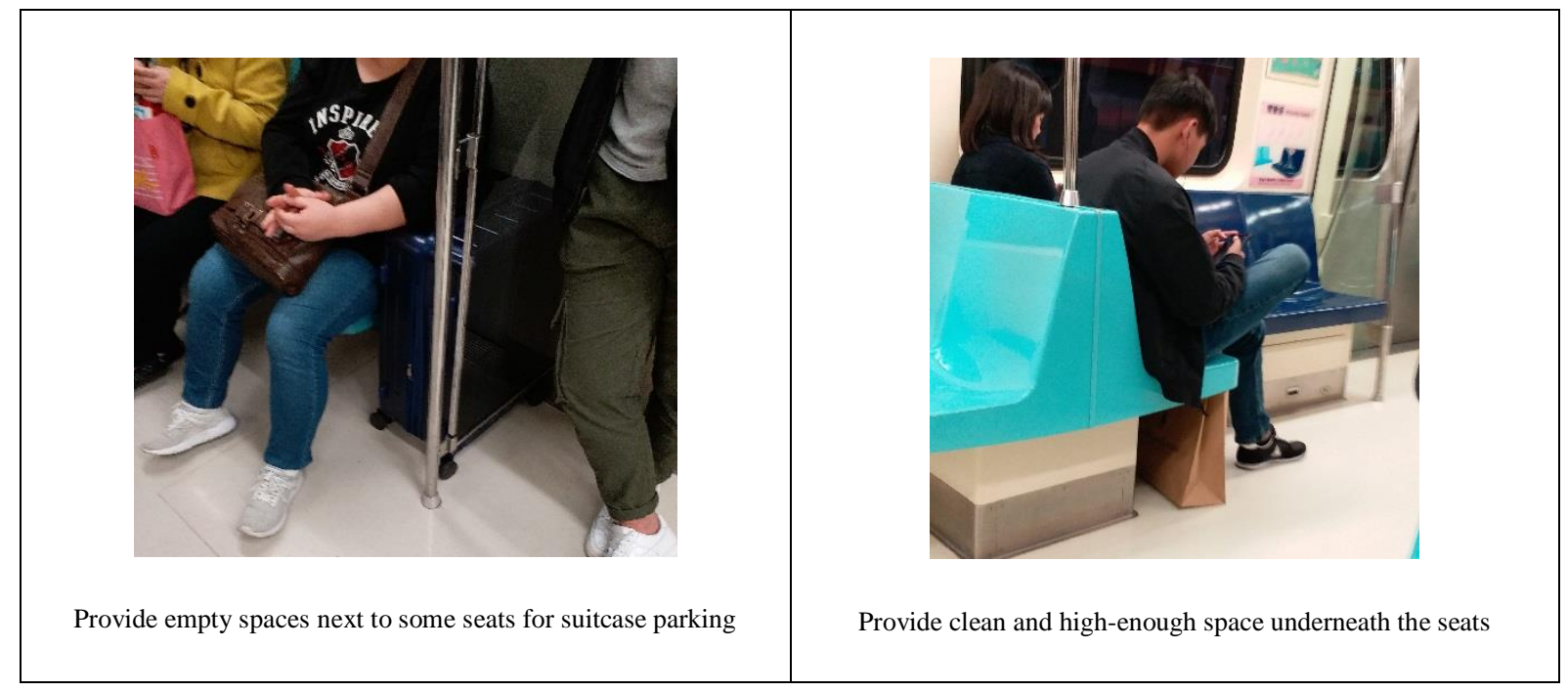

Source: Made by author.

To win customer satisfaction, urban rail lines are required to properly manage both the shared and the conflicting needs of the passengers not just inside the train cars but in every situation of using their services.

\section{CONCLUSION}


With the advancement of the society and rapid development of the service industry, couse has developed into a widespread format of service provision as well as major mode of consumption. Co-use favours both the consumers and the suppliers as it helps the former on saving expenses and the latter on raising the use of their services. To reduce complaints from users and conflicts between users, service providers are suggested carefully examine the situations in which their products and services are currently involved in co-use. Furthermore, QFD, introduced in the mid-1960s, has put forward an operation and a toolbox for service providers to explore the needs of each user groups of a co-use. Thorough understanding with the users' needs is fundamental to achieving quality.

Juran's famous notion "fitness for use" conveys the very essence of quality. Among the list of guidelines he laid down for checking whether a product is fit for use or not, "How will this product be used? What will be the environments of use?" and "Who will be the users?" are two important ones for service providers to manage the quality of co-use.

\section{Sažetak:}

UPRAVLJATI SURADNJOM RAZVOJA KVALITETE FUNKCIJE (QFD) ZA KVALITETU I ODRŽIVOST

Iako je zajednička upotreba učinkovita za održavanje naše jedine planete i korisna za korisnike i pružatelje usluga na tržištu, problemi s isporukom i korištenjem usluga zajedničke uporabe rastu. Žalbe korisnika i sukobi između korisnika u korištenju usluge postaju sve veći. Razlozi koji vode do problema mnogobrojni su. Međutim, iz perspektive upravljanja kvalitetom, glavni razlog je da potrebe zainteresiranih korisnika još nisu u potpunosti zadovoljene. Da bi se pružateljima usluga pomoglo u ublažavanju problema, cilj rada je razmotriti aspekte važne za primjenu uvođenja kvalitetne funkcije (QFD) kako bi se razumjelo potrebe korisnika koji su uključeni u zajedničku uporabu usluge i ponudilo neke prijedloge za upravljanje korištenjem usluga zajedničke uporabe. Rasprava o aplikaciji QFD i predloženi prijedlozi trebaju pomoći pružateljima usluga kako bi doprinijeli podizanju kvalitete isporuke i podržali ih u razvoju zajedničke uporabe kao načina za održavanje našeg društva i svijeta.

Ključne riječi: uvođenje funkcije kvalitete, ko-uporaba, održivost.

\section{REFERENCES}

1. Kogure, M., and Y. Akao, "Quality function deployment and CWQC in Japan: a strategy for assuring that quality is built into new products", Quality Progress, October, 1983.

2. Chan, Catherine Y. P., "QFD for achieving business excellence and attaining sustainability", Proceedings of the ISQM, Tainan, Taiwan, $19^{\text {th }}$ November, 2016.

3. Chan, Catherine Y. P., and G. H. Mazur, 'A framework of "use" for QFD', Transactions from the $25^{\text {th }}$ Symposium on Quality Function Deployment, Boise, Idaho, USA, $6^{\text {th }}-7^{\text {th }}$ September, 2019.

4. Ishikawa, K., Introduction to Quality Control, 3A Corporation, Tokyo, 1990.

5. Akao, Y., "History of quality function deployment in Japan", In: Zeller, H. J. (Ed.) The Best on Quality: Targets, Improvement, Systems, Vol. 3, Muchen: C. Hanser, 1990.

6. Chan, Catherine Y. P. and Palmira López-Fresno, "QFD: fundamentality for innovation", Proceedings of the $14^{\text {th }}$ International Conference on Intellectual Capital, Knowledge Management \& Organisational Learning, Hong Kong, $7^{\text {th }}-8^{\text {th }}$ December, 2017. 
7. Akao, Y., “An Introduction of quality function deployment", In: Akao, Y. (Ed.) Quality Function Deployment: Integrating Customer Requirements into Product Design, Cambridge, Mass.: Productivity Press, 1990.

8. Akao, Y., "Development history of quality function deployment", In Mizuno, S., and Akao, Y. (Eds.), QFD: The Customer-driven Approach to Quality Planning and Deployment, pp. 339-351, Tokyo, Japan: Asian Productivity Organization, 1994.

9. Akao, Y., "QFD: past, present and future", Proceedings of the $3^{\text {rd }}$ Annual International QFD Symposium”, Vol. 1, Linköping, Sweden, 1997.

10. Guinta, L. R., and Nency C., Praizler, The QFD Book: The Team Approach to Solving Problems and Satisfying Customers through Quality Function Deployment, Amercian Management Association, 1993.

11. Chan, Catherine Y. P., Palmira López-Fresno and Y. Akao, "QFD from Japan to Global:

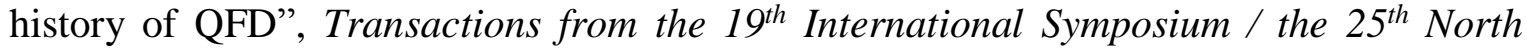
America Symposium on Quality Function Deployment, Santa Fe, New Mexico, USA, $6^{\text {th }}$ $7^{\text {th }}$ September, 2013.

12. Akao, Y., "A case study on the development of a folding bicycle", Transactions from International Symposium on QFD 2010-Portland / the $22^{\text {nd }}$ Symposium on Quality Function Deployment, Portland, Oregon, USA, $24^{\text {th }}-25^{\text {th }}$ September, 2010.

13. Friman, Ingela, "User requirements for electric wheelchairs", In Bühler, C., and Knops, H. (Eds.), Assistive Technology on the Threshold of the New Millennium, Washington DC: IOS; Tokyo: Ohmsha, 1999.

14. Bolt, A. and G. H. Mazur,"Jurassic QFD: integrating service and product quality function deployment", Transactions from the $11^{\text {th }}$ Symposium on Quality Function Deployment, Novi, Michigan, USA, $12^{\text {th }}-18^{\text {th }}$ June, 1999.

15. Ronney, E., Olfe, P. and G. H. Mazur,"Gemba research in the Japanese cellular phone market", Transactions from International Symposium on QFD 2000-Novi / the $12^{\text {th }}$ Symposium on Quality Function Deployment, Novi, Michigan, USA, 5 $5^{\mathrm{h}} 6^{\mathrm{h}}$ June, 2000.

16. Ekdahl, F., Gustafsson, A., and P. Norling, "QFD for service development: a case study from Telia Mobitel”, Proceedings of the $3^{\text {rd }}$ Annual International QFD Symposium”, Vol. 2, Linköping, Sweden, 1997.

17. Chan, C. Y. P., Chin, K. S., Chan, Candace and K. L. Tsui, “An analysis of passengers' ride needs of urban rail transit services: application of quality function deployment", International Journal of Quality Innovation, Vol. 5, No. 8, 2019.

18. Köksal, G., and Eğitman, A., "Planning and design of industrial engineering education quality", Computers Industrial Engineering, Vol. 35, No. 3-4, 1998.

19. Owlia, M. S., and E. M. Aspinwall, "Application of quality function deployment for the improvement of quality in an engineering department", European Journal of Engineering Education, Vol. 23, No. 1, 1998.

20. Boonyanuwat, N., Suthummanon, S., Memongkol, N., and Chaiprapat, S., "Application of quality function deployment for designing and developing a curriculum for industrial engineering at Prince of Songkla University", Songklanakarin Journal of Science Technology, Vol. 30, No. 3, 2008.

21. Desai, A., and J. Thomassian, "Engineering course design based on quality function deployment (QFD) principles: incorporation of diverse constituencies and continuous improvement", Proceedings of the $38^{\text {th }}$ ASEE/IEEE Frontiers in Education Conference, Session T2G, 2008. 